\title{
PERAN RUMAH BUDAYA TEMBI DALAM MELAHIRKAN KOMPONIS MUDA MELALUI AJANG FESTIVAL
}

\author{
Ganang Dwi Asmoro \\ Ganang.horn@yahoo.com
}

\begin{abstract}
Abstrak
Artikel dalam tulisan ini untuk mengetahui bagaimana peran Rumah Budaya Tembi dalam melahirkan komposer-komposer muda. Metode yang akan digunakan dalam penelitian ini adalah dengan pendekatan studi kasus. Metode pengumpulan data yang akan dilakukan dalam penelitian ini dengan melakukan observasi, wawancara dan studi pustaka. Sumber data ini diperoleh melalui informan, pustaka dan dokumen. Untuk menganalisis data penelitian ini, dilakukan dengan mereduksi data, penyajian data, memverifikasi atau penarikan kesimpulan. Hasil dari penelitian ini menunjukkan bahwa Rumah Budaya Tembi berperan terhadap munculnya komposer muda melalui ajang festival yang diselenggarakan. Festival musik Tembi yang diselenggarakan setahun sekali ini mampu memberikan wadah bagi para komposer muda untuk mengekspresikan imajinasinya dengan menghadirkan karya seninya .
\end{abstract}

Kata kunci : komposer, festival musik, Tembi

\section{Pendahuluan}

Dewasa ini komposer menjadi pilihan dan minat dalam berkarir oleh beberapa kalangan anak muda. Sebutan sebagai komposer memiliki kebanggaan tersendiri bagi para pelakunya. Tidak seperti jaman dahulu ketika penonton hanya menikmati sajian musik dan musisinya ketika di atas panggung, saat ini komposer memiliki peran dan kedudukan yang sama pentingnya. Meski sudah sama posisinya, tidaklah gampang untuk menemukan bakat-bakat komposer muda terlebih kepada komposer musik kontemporer atau musik gaya baru. Jenis musik tersebut tidak semua orang bisa menikmatinya ketika karya musik tersebut disuguhkan. Maka dari itu, untuk mencetak para komposer musik gaya baru yang baik, perlu peran serta dari institusi pendidikan dan juga komunitas yang sadar akan pentingnya mencetak para komposer.

Dalam lima tahun terakhir ini Rumah Budaya Tembi telah mengambil sikap akan masalah ini. Dengan menyelenggarakan acara Festival Musik Tembi, mereka menghadirkan pertunjukan musik dengan tema "Musik Tradisi Baru". Hal ini dibuat untuk menemukan bakat - bakat baru para komposer muda di Indonesia, sebab dalam eksekusinya mereka hanya mengundang komposer muda yang usianya tidak boleh lebih dari 35 tahun untuk menampilkan karya terbaiknya dalam Musik Tradisi Baru. Dan sejak diselenggarakan oleh Rumah Budaya Tembi dari lima tahun yang lalu, acara ini sudah banyak menelurkan ataupun mengorbitkan komposer-komposer muda yang sekarang sudah popular dalam komposisi musik gaya baru.

Festival Musik Tembi sendiri sudah berlangsung lebih dari lima tahun dan sejak pertama kali diselenggarakan pada 2011, Festival Musik Tembi terus konsisten dalam 
bermusik dan tidak pernah mengubah tujuan utamanya, yaitu sebagai wadah untuk memberikan ruang apresiasi bagi musisi dan komposer muda yang ingin berkreasi dalam bunyi-bunyian nusantara tanpa sekat genre (liputan6.com).

Di dalam pertunjukan festival musik ini, karya musik yang dipertunjukan lebih fokus kepada karya musik tradisi baru. Komposisi musik yang yang lebih mengedepankan unsur musik tradisional yang ada di Indonesia dan tentunya karya yang dimainkan adalah yang orisinil dan belum pernah dipentaskan di tempat lain. Dengan tema musik tradisi baru, diharapkan festival ini bisa menemukan komposer muda yang berbakat, berkualitas, berpengetahuan barat yang tidak meninggalkan musik tradisi yang ada di Indonesia.

Artikel tentang komponis muda sebenarnya banyak disinggung oleh Suka Harjana dalam bukunya Esai dan Kritik musik serta bukunya yang berjudul Musik : Antara Kritik dan Apresiasi. Dalam artikel yang ditulis di buku itu, Suka Harjana lebih banyak mengungkapkan tentang Pekan Komponis Muda yang diselenggarakan pada dekade 80 hingga 90-an oleh Dewan kesenian Jakarta untuk melahirkan para komposer. Saat ini, festival Pekan Komponis Muda sudah lama tidak terdengar lagi dan hanya sedikit dari institusi atau lembaga swasta yang tetap konsisten dalam membuat program pertunjukan musik kontemporer, salah satunya adalah Rumah Budaya Tembi. Lalu apa yang membuat Rumah Budaya Tembi mau untuk melahirkan para komposer? Bagaimana cara Rumah Budaya Tembi mengakomodasi para komposer muda?

Komposer adalah julukan dari seorang arranger dan penulis lagu yang mengkomposisi nada-nada menjadi musik. Komposer memiliki kebebasan yang abstrak dalam menciptakan sebuah karya musik, sebab dialah orang pertama dalam membuat komposi. Banyak dari mereka yang mampu untuk menulis lagu, namun tidak mampu untuk membuat komposisi musik dari berbagai instrumen yang dipadukan secara baik. Oleh sebab itu untuk menjadi seorang komposer tidaklah semudah apa yang kita bayangkan.

Sebab pada setiap kreatif dalam penciptaan komposisi memerlukan berbagai pendekatan, Pangabean (2006) mengemukakan beberapa pendekatan dalam proses kreatif dari seorang komposer, diantaranya adalah pendekatan tradisi maupun nontradisi, reinterpretasi (orientasi untuk menampilkan repertoar yang sudah ada menjadi sesuatu yang baru) dan yang terakhir adalah kontemporer (sebuah orientasi melepaskan diri dari kebiasaan yang sudah ada atau kemungkinan mendapatkan hal yang baru). Seorang komposer akan menggunakan struktur teori musik dan organologi musik yang komprehensif dalam membuat karya komposisi, di samping itu seorang komposer juga harus mengetahui ilmu sosiologi, psikologi dan antropologi.

Disiplin ilmu yang lain itu diperlukan untuk menunjang komposer dalam membuat komposisi musik, sebab membuat komposisi musik tidak hanya dengan dengan modal merenung sambil menunggu inspirasi yang datang. Tanpa pengetahuan musik yang memadai dan keterampilannya dalam mengolah cita rasa musik yang humanis, seorang komponis tidak akan mampu untuk membuat suatu komposisi musik yang baik. 


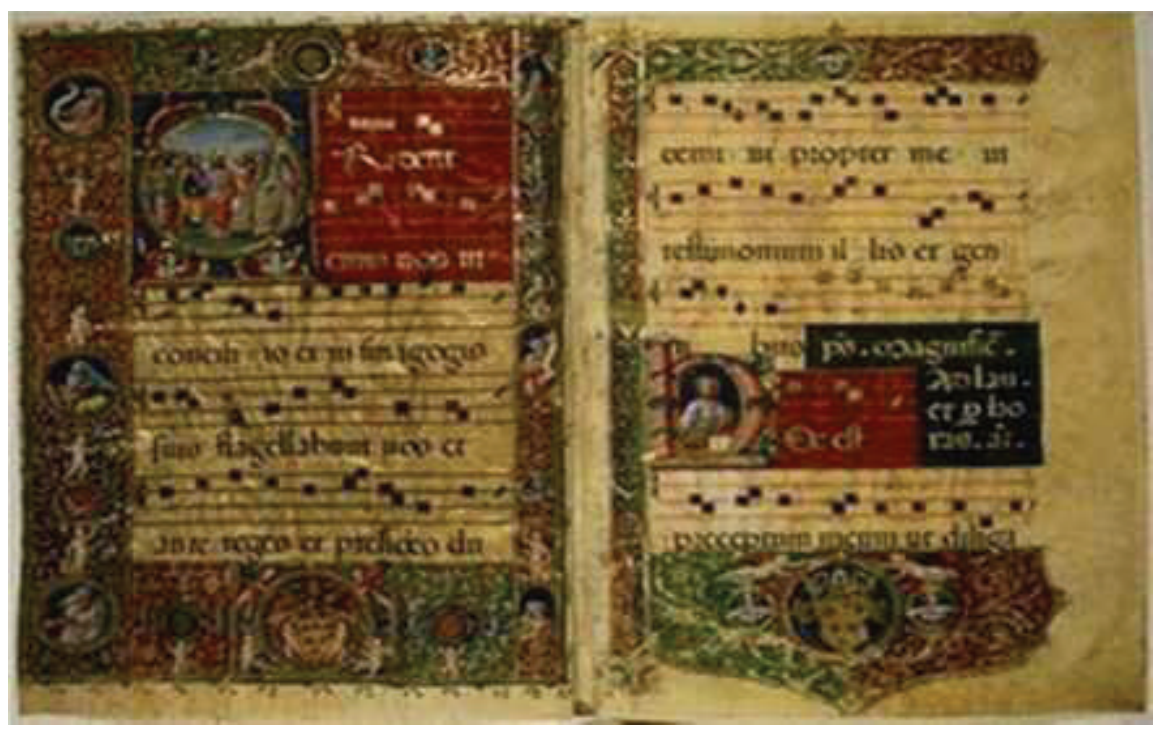

Gambar 1: Awal mula tulisan notasi musik

Pada awal perkembangan musik di barat, komposer membuat komposisi musik dengan simbol-simbol tulisan supaya bisa dimainkan oleh para musisi. Simbol-simbol itu berkembang menjadi notasi musik atau lebih dikenal dengan not balok. Pada abad ke 19 para komposer menggunakan tulisan tangan dalam membuat komposisi untuk dituliskan ke dalam notasi. Cara membuat komposisi oleh komposer mulai berubah ketika komputer ditemukan. Terlebih ketika beberapa software untuk membuat komposisi musik seperti Sibelius, finale dan software musik lainnya. Dengan perkembangan mekanik dan sistem yang lebih cepat inilah, maka banyak musisi atau komposer menggunakan computer sebagai tempat bekerja untuk mewujudkan ideide atau kreativitas yang dimilikinya, Widodo (2006).

Program-program musik itu berkembang sesuai jaman hingga muncullah banyak program musik yang mampu meringankan beban para komposer dalam membuat komposisi. Keterlibatan komputer dalam proses komposisi musik sebenarnya bukanlah menjadi barang yang baru. Pada tahun 50an, Max Mathews mengembangkan program suara sintesis pada AT\&T, kemudian untuk beberapa dekade, komputer telah digunakan untuk melakukan proses komposisi musik, biasanya menggunakan metode probabilitas atau metode stokastik, dan banyak lagi pengembangan-pengembangan komputer di bidang musik lainnya, Jacob (2000).

Meski ada komposer yang masih menggunakan notasi yang umum dalam menulis komposisi musik, dalam perkembangannya ada beberapa para komposer yang menuliskan lebih banyak dengan simbol-simbol dan keterangan untuk dimainkan alat musik yang ada di dalam karya komposisi.

Banyak orang bertanya, apa itu musik tradisi baru? Musik tradisi baru adalah perkembangan dari musik modern, new musik dan juga bisa dibilang kontemporer. Hanya saja musik tradisi baru ini tidak hanya menggunakan alat musik barat saja akan tetapi juga memadukannya dengan alat musik tradisi dalam hal ini adalah alat musik etnik pada suatu daerah tertentu. Pengertian musik tradisi baru ini hanyalah sebutan semata, sebab pada umumnya istilah lebih terkenal dengan sebutan musik kontemporer. Arti kontemporer sendiri menurut Guralnik dalam Sal Murgiyanto (2016), berasal dari atau dalam gaya masa kini atau yang mutakhir. Arti tersebut sering dipakai dalam dunia kesenian dan dekat dengan arti kata 
'modern' yaitu: (1) dari atau berkaitan dengan gaya, metode, atau gagasan terbaru; tak ketinggalan zaman; dan (2) berhubungan dengan 'trend' dan aliran seni rupa, musik, sastra, tari dan sebagainya.

Pandangan orang terhadap musik adalah suatu rangkaian nada sedemikian rupa satu sama lain hingga menjadi sebuah harmonisasi yang indah. Jenis-jenis musik memiliki banyak ragamnya, namun begitu perkembangan musik tentu kita harus berkiblat ke barat mulai dengan musik renesaine, barok, klasik, romantic, hingga modern. Selanjutnya berkembanglah aliran musik post modern. Di era postmodern itulah muncul istilah dari barat dengan musik kontemporer. Suatu jenis musik yang diluar pakem pada umumnya ketika komposer pembuatnya menuangkan kritikan ketidaknyamanannya terhadap musik yang menjenuhkan. Musik kontemporer adalah alternatif musik untuk dinikmati dengan rasa yang berbeda pada umumnya. Hingga pada abad ke-19 musik kontemporer ini sampai ke Indonesia.

Perkembangan musik kontemporer di Indonesia begitu masif dengan berbagai jenisnya, namun menurut Mack, dalam tulisan Ishak (2013) mengatakan keberadaan jenis musik kontemporer di Indonesia menjadi tiga bagian yaitu:

\section{a. Musik Kontemporer dalam Idiom Tradisi Barat}

Tokoh komposer dalam musik ini adalah Amir Pasaribu, Dua Srikandi piano: Trisutji Kamal dan Marusya Nainggolan Abdullah. Materi musiknya berupa musik tradisional akan tetapi teknik garapannya memakai prinsip-prinsip pada musik barat. Misalnya nuansa gendhing gamelan Jawa yang ditranskripsikan ke dalam piano. Sudah tentu, masalah laras dan alur musiknya bukan lagi pelog, slendro ataupun ladrang, melainkan misalnya mengambil bentuk sonata, prelude dan semacamnya.

\section{b. Musik Kontemporer yang Bersumber dari Unsur Etnik}

Tokoh komposer ini dimotori oleh A.W.Sutrisna, Rahayu Supanggah, Wayan Sadra, Dody, Satya, Diman. Para komponis ini yang banyak mendapat pujian di Jerman. Karya-karya dalam musik kontemporer kategori ini bisa dikatakan sebagai sebuah revitalisasi musik tradisi. Misalnya dengung Sunda yang cara memainkannya dengan sendok makan. Lalu memainkan kecapi dengan menggunakan gesekan kuku jari. Tata gramatik musik pun mendapat pakem baru, misalnya perubahan fungsi di setiap instrumen dan kemungkinan peran sebagai solis pada tiap instrumen etnik. Sebab pada dasarnya Degung klasik yang murni adalah sebuah ansambel.

\section{c. Musik Baru yang Berlatar Belakang Budaya Indonesia dan Budaya Barat}

Tokoh komponis dalam ini adalah Slamet Abdul Syukur, Alm. Sapto Ragardjo, Alm.Ben Pasaribu, Tony Prabowo, dan Oto Sidharta. Ciri-ciri dari jenis musiknya berupa campuran dua macam musik barat dan musik tradisional, misalnya dalam karya Slamet Abdul Syukur yang berjudul Tetabuhan Sungut yang berupa canon vocal akan tetapi strukturnya mengambil teknik garapan gendhing.

Dari berbagai jenis musik kontemporer yang berkembang di Indonesia, ada sosok yang fenomenal disebut sebagi bapak musik kontemporer. Adalah sosok Slamet Abdul Syukur yang selalu konsisten dengan perkembangan jenis musik ini. Suka harjana (2004: 261) menyebut Slamet adalah penyebar pertama musik kontemporer di Indonesia. Dan ketika masuk ke 
Indonesia, musik kontemporer masih sangat susah untuk diterima telinga masyarakat kita hingga membuat perdebatan diantara para tokoh-tokoh musik di tanah air. Perdebatan itu lebih banyak dalam istilah kontemporer yang susah diartikan bila diterjemahkan. Hal inilah yang membuat bingung bagi pelaku musik, sebab beberapa tokoh musik dan komposer musik di Indonesia memberikan persepsi yang berbeda-beda terhadap musik kontemporer. Hal yang demikian ini mungkin bisa dimaklumi, sebab terminologi kontemporer Barat inipun di "Barat" tidak ada yang bisa menjelaskan, kendati pun banyak diantara mereka yang mencoba merekareka (Harjana, 2004: 187).

Untuk mengetahui dan memahami musik kontemporer tidaklah mudah, sebab setiap oaring memiliki latar belakang dan pengalaman bermusik yang berbeda-beda. Namun, pada dasarnya kita bisa mengetahui dan mengenali jenis musik kontemporer dengan berbagai macam ciri yang ada di dalam bentuk komposisi musik tersebut. Suka Harjana (2004: 331) mengatakan, salah satu ciri musik kontemporer abad ke-20 di samping doktrin-doktrin kompisitorisnya adalah bentuk-bentuk musicianship dalam formasi kecil sampai ansambel madya, baik dalam instrumen gesek, orkestra, tiup, campuran maupun lebih-lebih ansambel tetabuhan. Masih ada ciri-ciri musik kontemporer yang lainnya yang dapat dikenali kenali, diantaranya adalah judul dari setiap komposisi biasanya terlihat unik, simple, aneh atau bahkan terkesan lucu.

Selanjutnya adalah teknik dalam memainkan instrumen musiknya yang tidak baku atau sebagaimana biasanya, misalnya instrumen musik Gong di gesek, adapula alat musik orksetra yang menirukan suara alat tradisional seperti Sharon, gender, kendang dan lainya. Ciri yang mungkin umum adalah penulisan dalam notasi komposisinya. Komponis kontemporer biasanya hanya memberikan bentuk ilustrasi, tulisan dan simbol-simbol dalam notasi musik yang ala kadarnya. Hal seperti itu hanya diketahui oleh komposer dan musisi yang memainkan karya komposisi itu sendiri.

Apapun ciri dalam musik kontemporer yang paling utama adalah konsep bunyi dan konsep komposisi yang akan disampaikan oleh penciptanya itu sendiri. Apa sebenarnya maksud dan keinginan yang mau disampaikan oleh si penciptanya? Apakah sudah sesuai dengan apa yang direncanakan ketika karya itu ditampilkan di atas panggung? Apakah konsep yang akan ditampilkan dalam komposisi itu benar-benar musik kontemporer? Sebab apa yang terjadi selama ini, persepsi dari setiap orang itu berbeda-beda. Begitu juga dengan persepsi dari penonton dan pencipta karya itu sendiri. Untuk itu biar lebih fair dalam penilaiannya perlu dihadirkan pula para kritikus musik untuk mengapresiasi karya musik kontemporer supaya komposer tidak mengelabuhi penonton.

Tembi Rumah Budaya adalah tempat penyimpanan dokumentasi sekaligus memberikan informasi tentang sejarah dan kebudayaan Jawa yang berlokasi di Kabupaten Bantul Provinsi Yogyakarta. Tembi Rumah Budaya juga merupakan saksi dari lahirnya karya-karya kreatif yang berbasis kepada masyarakat lokal. Rumah budaya ini sering menyelenggarakan berbagai macam kegiatan seni budaya seperti pameran senirupa, pertunjukan seni tradisional maupun seni kontemporer, pentas tari dan teater, musik, hingga pertunjukan seni baca puisi. Untuk membiayai pengelolaan, Tembi Rumah Budaya ini tidak tidak mengandalakan sokongan dana dari lembaga manapun. Semua kegiatan yang diselenggarakan adalah bersifat nirlaba atau non profit dan untuk memenuhi kebutuhan pengeluaran, Tembi mendapatkan pemasukan dari 
fasilitas seperti bale karya, bale rupa, bale inap, museum, perpustakaan, kolam renang, dan warung makan.

Sejarah Desa Tembi dahulunya adalah salah satu tempat para abdi dalem katemben yang tugasnya menyususi anak-anak dan kerabat Keraton Maka desa ini kemudian dinamai desa Tembi.Di desa itulah Museum Rumah Budaya Tembi (Tembi House of Culture)berdiri cukup mencolok di pinggir jalan. Museum ini menempati tanah seluas 3.500 meter persegi dengan dengan luas bangunan utama 212 meter persegi dan luas seluruh bangunan mencapai 1.057 meter persegi. Museum ini mengkhususkan diri pada kebudayaan Jawa. Saat ini desa Tembi sendiri merupakan kawasan kampung kerajinan yang menyakup GMT (Gabusan Manding - Tembi).

Di museum Rumah Budaya Tembi ini memiliki beberapa koleksi yang variatif, berupa peralatan tradisional Jawa antara lain peralatan dapur seperti tungku, dandang (alat untuk memasak), senjata berupa keris dan tombak, peralatan bertani berupa bajak, kolam renang, peralatan seni gamelan dan batik, dan juga foto foto jaman dahulu, poster kuno bahkan ada sepeda motor kuno serta perpustakaan dengan jumlah naskah yang mencapai 5.000 buah. Tempat ini juga menyediakan ruang untuk pameran, pertemuan, tempat penginapan, restaurant, kolam renang dan pendopo beserta seperangkat alat gamelan.

Dalam setiap bulannya, di tempat ini digelar kegiatan rutin berupa pertunjukan tari dari berbagai daerah di Indonesia, pertunjukan wayang dengan dalang lokal, pameran senirupa, musik, baca puisi workshop, diskusi, dan seminar. Tembi juga tidak lupa untuk memperkenalkan kebudayaan jawa kepada pengunjung dengan menyelenggarakan kegiatan bertemakan tradisional seperti membajak sawah dengan sapi, membatik, berlatih gamelan, permainan anak-anak, dan lain sebagainya.

Rumah Tembi ini memiliki wadah berkesenian untuk kegiatan bermusik yang bernama FOMBI, kepanjangan dari forum musik tembi. Indra (2016) mengemukakan forum ini yang mewadahi kegiatan musik yang ada di Rumah Tembi. Salah satu kegiatan yang paling fenomenal adalah Festival Musik Tembi. Melalui festival ini, pertunjukan yang bertemakan Musik Tradisi Baru mengakomodasi para komposer-komposer muda yang ingin menampilkan karya karya idealisnya. Festival musik yang diselenggarakan oleh Tembi, saat ini sudah berlangsung sejak enam tahun yang lalu dengan mengambil tema yang berbeda-beda, namun dalam festival musik ini tidak jauh dari musik tradisi baru yang menghadirkan bunyi-bunyi nusantara dengan kemasan bentuk musik barat.

Peran festival musik tembi dalam menyelenggarakan pertunjukan musik tradisi baru cukup baik. Awal cerita dari penyelenggaraan festival ini berawal dari perbincangan Forum Musik Tembi dengan antropolog dan budayawan, Lono Simatupang pada awal tahun 2011. Saat itu muncul perbincangan bahwa ruang kreasi untuk pengembangan musik tradisi Nusantara masih sangat dibutuhkan oleh para pelaku musik. Lono mengatakan, Festival Musik Tembi yang akan digelar akan dipandang sebagai ruang yang tepat untuk mengakomodasi munculnya berbagai ide kreatif dan olahan-olahan komposisi musisk baru dari para pencipta komposisi dengan bahan dasar musik tradisi Nusantara. Komposisi tersebut bersifat bebas yang tidak terikat dari segi instrumenasi, ritme tradisi, idiom musik maupun nuansa musik yang dipengaruhi oleh unsur musik tradisi.

Dari perbincangan sebagai ide dasar itu, tim FOMBI menyambut antusias dan mengolahnya menjadi rencana nyata dengan menyiapkan sebagai bagian dari Festifal Musik 
Tembi 2011. Panggung muncul sebagai salah satu program dari rangkaian tiga hari FMT yang akan diselenggarakan. Untuk menarik para musisi bergabung dalam Panggung musik tradisi baru, dibukalah audisi dengan tagline: 'Dicari Musik Tradisi Baru' 2011 dengan beberapa syarat, diantaranya peserta berusia 17-35 tahun dengan mengirimkan rekaman karya mereka.

Animo dari para pelaku musik yang ingin bergabung dengan acara festival musik cukup baik. Belasan group musik dari beberapa daerah mengirimkan karya mereka untuk diseleksi. Para komposer muda yang membawa group ansambel dalam dalam mengikuti festival musik ini memiliki berbagai macam latar belakang. Ada yang dari lingkungan akademisi, ada juga yang berlatar belakang musik tradisi, ada juga yang hanya penghobi musik saja. Namun dari keberagaman itu, festival musik ini dapat mampu memberikan warna dalam keberagaman pengalaman bermusik dari setiap karya yang dihadirkan oleh para komposer-komposer muda tersebut. Yang menarik dari setiap penyelenggaran festival musik ini adalah para komposer yang ingin menghadirkan karya selalu membawa kelompok ansambel musiknya.

Nama dari kelompok musik itu sendiri biasanya yang mewakili nama para komposernya. Jadi banyak dari komposer atau leader dari kelompok tersebut mengatakan " ini karya komposisi kelompok kami”. Jarang sekali dari beberapa kelompok yang hadir dalam musik tradisi baru yang mengatakan karya komposisi itu dari nama dari pembuat komposisi tersebut. Sebab banyak dari kelompok tersebut yang membuat komposisi secara bersama-sama mengikuti keinginan dari anggota kelompok tersebut.

Karya-karya dari para komposer muda dalam festival musik ini sudah cukup banyak. Dari banyaknya karya-karya dari peserta tersebut, penyelenggara festival ini memilih beberapa karya terbaik. Karya-karya dari komposisi terbaik itu lalu di rekam untuk di buat album kompilasi. Dari sejak tahun 2011 sampai sekarang sudah dibuat beberapa album kompilasi yang mengkhususkan tentang musik tradisi baru.

Pada tahun 2015 dan 2016 acara festival musik yang diselnggarakan oleh Tembi melalui musik tradisi baru berjalan dengan sukses seperti acara-acara sebelumnya. Hal ini terlihat dari antusiasnya dari para penonton juga cukup banyak, namun karya karya dari para komposer muda dalam festival itu tidak terekam dengan baik untuk dijadikan album kompilasi seperti halnya di tahun tahun sebelumnya. Meski begitu, dengan diselenggarakannya festival musik tradisi baru, Tembi Rumah Budaya mampu menunjukkan perannya sebagai pengelola untuk mengakomodasi para komposer-komposer muda yang ingin menampilkan karyanya. Hal ini terlihat dari banyaknya para peserta yang ingin menampilkan karya musiknya. Dengan begitu akan terlihat bakat-bakat yang baik dari para komposer muda, maka pelaku seni khususnya musik akan melihat bagaimana peran Tembi Rumah Budaya dalam sumbangsihnya melahirkan para komposer muda melalui ajang festival musik.

\section{Kesimpulan}

Setelah uraian di atas, maka dapat disimpulkan bahwa apa yang membuat Rumah Budaya Tembi mau untuk melahirkan para komoser muda ini dikarenakan masih sedikitnya ruang berkreasi untuk para komposer muda. Lono Simatupang mengungkapkan, bahwa tempat berkreasi untuk musik nusantara sangat diperlukan oleh pelaku musik khususnya musik kontemporer. Maka dari pembicaraan dengan forum musik tembi dengan Lono Simpatupang 
dibentuklah suatu kegiatan festival musik yang bertemakan Musik Tradisi baru dengan mengedepankan pada ekplorasi musik dan instrumen dari nusantara. Jenis-jenis komposisi musik tradisi baru sendiri sebenarnya tidaklah asing di telinga kita, sebab pada dasarnya kita sering mendengarkanya. Hanya saja dalam musik tradisi baru ini perlu dihadirkan maksud dan tujuan dari komposer dalam mengkomposisi musik tradisi baru tersebut. Apakah maksud dan tujuan dalam komposisi musik yang dihadirkan itu bisa terlihat dari teknik bermain, konsep dan ide saat dipertunjukan? Tentunya ajang festival ini juga menghadirkan kritikus musik yang dapat mampu menerjemahkan maksud daripada karya tersebut kepada penonton yang hadir dalam pertunjukan musik tradisi baru.

Festival Musik Tembi dalam menghadirkan musik tradisi baru ini cukup memberikan ruang bagi para pelaku seni khususnya para komposer musik kontemporer yang berangkat dari musik tradisi. Hal ini dibuktikan dengan banyaknya dari kelompok seni ataupun individu yang terlibat di dalam acara tersebut. Dan dari ajang festival ini muncul banyak nama-nama komposer muda yang mulai banyak terlihat di berbagai pertunjukan ataupun festival musik kontemporer di Indonesia. Semoga Festival Musik Tembi dapat mampu memberikan sumbangsihnya dalam memberikan edukasi musik terhadap masyarakat khususnya masyarakat seni yang masih haus akan apresiasi terhadap musik tradisi baru.

\section{Kepustakaan}

Mack, Dieter.2004. Musik Kontemporer dan Persoalan Interkultural, Bandung: ARTI.

Hardjana, Suka. 2004. Esai Dan Kritik Musik, Yogyakarta : Galang Press 2004.Musik Antara Kritik dan Apresiasi, Jakarta: Kompas.

Jacob (2000). Algorithmic Composition as A Model of Creativity, Advance Computer Architecture Lab, EECS Departement, University of Michigan

Murgiyanto, Sal.2016. Pertunjukan Budaya Dan Akal Sehat,Jakarta : Fakultas Seni Petunjukan - IKJ Komunitas SENREPITA

Pangabean.2006. Proses Penciptaan Dalam Pengalaman Diri. Etnhomusikologi, vol.2 no.1, Mei 2006 1- 9

Widodo.2006. Komputer Dan Pengetahuan program Aplikasi Musik Komputer. Harmonia, journal of art research and education, Semarang state University.

http://lifestyle.liputan6.com/read/2508753/merayakan-bunyi-bunyian-tradisional-di-festivalmusik-tembi : diakses tgl 3 Desember 2016 pikul 12;00

http://ishak-mohamad.blogspot.co.id/2013/05/musik-kontemporer.html : di akses 2 Mei 2016 https://id.wikipedia.org/wiki/Museum_Rumah_Budaya_Tembi : diakses 2 Mei 2016

Indra waskito.Panitia festival musik tembi. Wawancara pada tanggal 28 April 2016 